Summer 2013

\title{
A Diamond Scheme is Forever Lost: The Kimberley Process's Deteriorating Tripartite Structure and its Consequences for the Scheme's Survival
}

Andrew $\mathrm{H}$. Winetroub

Indiana University Maurer School of Law, ahwine@gmail.com

Follow this and additional works at: https://www.repository.law.indiana.edu/ijgls

Part of the Banking and Finance Law Commons, International Law Commons, and the International Trade Law Commons

\section{Recommended Citation}

Winetroub, Andrew H. (2013) "A Diamond Scheme is Forever Lost: The Kimberley Process's Deteriorating Tripartite Structure and its Consequences for the Scheme's Survival," Indiana Journal of Global Legal Studies: Vol. 20 : Iss. 2 , Article 29.

Available at: https://www.repository.law.indiana.edu/ijgls/vol20/iss2/29

This Note is brought to you for free and open access by the Law School Journals at Digital Repository @ Maurer Law. It has been accepted for inclusion in Indiana Journal of Global Legal Studies by an authorized editor of Digital Repository @ Maurer Law. For more information, please contactrvaughan@indiana.edu.

\section{$\Psi$}

JEROME HALL LAW LIBRARY

INDIANA UNIVERSITY

Maurer School of Law
Bloomineton 


\title{
A Diamond Scheme is Forever Lost: The Kimberley Process's Deteriorating Tripartite Structure and its Consequences for the Scheme's Survival
}

\author{
ANDREW H. WINETROUB*
}

ABSTRACT

Oversight of the multi-billion dollar global diamond trade involves state actors, multinational corporations, and sophisticated civil society groups operating under the umbrella of the Kimberley Process. This unique tripartite governance structure created an opportunity for the parties to develop a system in which conflict diamonds could not enter the stream of commerce, transparency would be institutionalized, and governments and industry participants would be held to account. Yet, the successes of the Kimberley Process are increasingly jeopardized by an overly statist approach that has led to subjugation of the participating nongovernmental organizations. This note argues that for the Kimberley Process to regain its legitimacy, it must reform by recommitting to civil society's central role, increasing transparency within the diamond industry, and refusing to shield governments from enforcement of its rules.

\section{INTRODUCTION}

The Kimberley Process stands on the precipice of failure. In 2011, civil society boycotted the annual plenary meeting and Global Witness, one of two founding nongovernmental organization partners, withdrew from its central role in the certification scheme. The Kimberley Process was once lauded for bringing together governments, the diamond

* J.D. 2013, Indiana University Maurer School of Law; B.A. 2008, University of Kansas. I would like to thank Professor Christiana Ochoa for her inspiration and assistance in the writing process, as well as the staff of the Indiana Journal of Global Legal Studies for its tireless efforts in preparing this note. Additionally, I am grateful to my fiancée and my family for their constant support and positivity throughout my legal education.

Indiana Journal of Global Legal Studies Vol. 20, Issue 2 (2013)

(C) Indiana University Maurer School of Law 
industry, and civil society to collaboratively tackle the problem of conflict diamonds. Yet, despite successfully reducing the number of conflict diamonds in the supply chain, consumers remain unable to purchase a diamond with certainty that it was not illicitly mined. The Kimberley Process can regain its legitimacy through reforms that reengage civil society and allow for meaningful monitoring and enforcement mechanisms.

\section{The KImberley Process: CReated to Eliminate Diamonds as A FUNDING SOURCE FOR REBEL GROUPS IN ORDER TO PROTECT A VIBRANT DIAMOND TRADE}

Diamond exporting and importing governments, the diamond industry, and civil society groups founded the Kimberley Process Certification Scheme (KP) in 2002 at a meeting in Interlaken, Switzerland. ${ }^{1}$ Following investigations by nongovernmental organizations (NGOs) that uncovered the role of diamonds in funding conflicts in a number of diamond extracting states, the U.N. General Assembly passed a resolution urging the creation of an international regime to address the problem. ${ }^{2}$ After an initial meeting of all interested parties in Kimberley, South Africa, the General Assembly supported the proposed certification scheme for rough diamonds and the KP was subsequently finalized. ${ }^{3}$ Thus, the KP came into existence with widespread international support, in addition to featuring a promising tripartite governing structure to give civil society a voice in decision-making.

Conflict diamonds began to draw the international community's attention in the late $1990 \mathrm{~s}^{4}$ At that time, the role of diamonds in financing violent conflicts in sub-Saharan Africa was becoming increasingly clear, as rebel groups were laundering the prized resource in Angola, Sierra Leone, Liberia, and the Democratic Republic of the Congo (DRC). ${ }^{5}$ Sierra Leone provides just one example of how the

1. See Interlaken Declaration of 5 November 2002 on the Kimberley Process Certification Scheme for Rough Diamonds, KIMBERLEY Process, 1-2 (Nov. 5, 2002), http://www.kimberleyprocess.com/documents/10540/11192/0005_Interlaken_declaration_e n.pdf?version $=1.0 \& \mathrm{t}=1327412628000$ [hereinafter Interlaken Declaration].

2. See G.A. Res. 55/56, at 1-2, U.N. Doc. A/RES/55/56 (Dec. 1, 2000).

3. See Interlaken Declaration, supra note 1 , at 1.

4. See Seth A. Malamut, Note, A Band-Aid on a Machete Wound: The Failures of the Kimberley Process and Diamond-Caused Bloodshed in the Democratic Republic of the Congo, 29 SuffolK TRANSNAT'L L. REV. 25, 29 (2005) (referencing the U.N. Security Council's recognition of the role of diamonds in producing conflict).

5. See id.; Lesley Wexler, Regulating Resource Curses: Institutional Design and Evolution of the Blood Diamond Regime, 31 CARDozo L. REV. 1717, 1719 (2010). 
particularly acute role of diamonds is driving the conflict. ${ }^{6}$ Smuggled diamonds were the primary funding mechanism for the Revolutionary United Front (RUF) rebels, while the alluvial diamond fields in the east of the country served as the RUF's base and constituted the conflict's primary battlefield. ${ }^{7}$ As a physically small, highly valuable resource, diamonds were easily transported out of the conflict zone to a diamond industry serving demanding consumers around the world. 8 These illicitly mined rough diamonds were accepted by the diamond industry for years during similar conflicts, but practices began to change in 2000 when De Beers, the world's largest diamond company, announced it would cease trading with groups operating from conflict area mines. ${ }^{9}$

The diamond industry, finally acknowledging its essential role in moving rough diamonds from exporting states, could not avoid the conflict diamond issue as awareness of the conflicts in Africa grew. ${ }^{10}$ As governments and civil society groups began to act, so too did the diamond industry by participating in the creation of the KP and by creating its own standards through the World Diamond Council (WDC). ${ }^{11}$ The industry's internal auditing mechanism is the System of Warranties, "a voluntary industry scheme which encourages companies to place a statement on invoices declaring the enclosed diamonds to be conflict-free." 12 While the industry's participation in the effort to eradicate conflict diamonds is necessary, diamond companies have a strong self-interest in protecting the reputation of their product. Rather than seeking to ban the diamond trade, the KP buttresses the market with its internal controls to allow the seventy-two billion dollars in annual diamond sales to continue. ${ }^{13}$

The KP was founded to protect the diamond trade from conflict-producing rebel groups that were seen as the primary threat to

6. See Margo Kaplan, Note, Carats and Sticks: Pursuing War and Peace Through the Diamond Trade, 35 N.Y.U. J. IN'T'L L. \& POL. 559, 566-68 (2003).

7. Id. at $567-68$.

8. See Malamut, supra note 4, at 27-28.

9. Tracey Michelle Price, The Kimberley Process: Conflict Diamonds, WTO Obligations, and the Universality Debate, 12 MinN. J. Global TraDe 1, 32 \& n.255 (2003).

10. See About WDC: History, WORLD DLAMOND COUNCIL, http://www.worlddiamond council.com (last visited Mar. 12, 2013) (describing the establishment of the WDC in an effort to increase industry involvement in the conflict diamond issue).

11. See id.

12. The Diamond Industry, GLOBAL WITNESS, http://www.globalwitness.org/campaigns/ conflict/conflict-diamonds/diamond-industry (last visited Mar. 12, 2013).

13. See World Diamond Council, The Diamond Industry Fact Sheet 1 (2008), available at http://www.worlddiamondcouncil.org/download/resources/documents/Fact\%20 Sheet\%20(The\%20Diamond\%20Industry).pdf. 
an exclusively conflict-free diamond market. ${ }^{14}$ The objective was sufficiently broad to bring governments, the industry, and civil society together under the umbrella belief that "urgent international action is imperative to prevent the problem of conflict diamonds from negatively affecting the trade in legitimate diamonds, which makes a critical contribution to the economies of many of the producing, processing, exporting, and importing states, especially developing states." 15 As such, the KP can be seen as an attempt to address a specific resource curse by eliminating the deleterious effects of conflict diamonds on member states and, instead, channeling funds into legitimate state accounts. ${ }^{16}$ Reversing the natural resources trap that has engulfed a number of diamond exporting states is much needed for their development, but the $\mathrm{KP}$ must be reformed if it is to fulfill that vital mission. ${ }^{17}$

\section{THE KP OPERATES LARGELY AS A SYSTEM OF DOMESTIC LaWS, With THE DIAMOND INDUSTRY AND CIVIL SOCIETY BOTH PARTICIPATING AS OFFICIAL OBSERVERS}

At its founding, the KP offered the international community an opportunity to create an institution that would serve the interests of populations who have long suffered as a result of diamond extraction and trade. Yet, from the beginning, the concerns of member governments have dominated the legal regime, including control of the monitoring and enforcement mechanisms. ${ }^{18}$ Despite the potential for an inclusive organization with broad participation, states and the industry are threatening the KP's legitimacy by failing to adequately address diamonds that continue to fund violence and human rights abuses, as exhibited by the Marange diamond fields case in Zimbabwe that led to Global Witness's departure from the KP. ${ }^{19}$

14. See Kimberley Process Certification Scheme, KIMBERLEY PROCESS, at 1, available at http://www.kimberleyprocess.com/documents/10540/11192/KPCS\%20Core\%20Document?v ersion $=1.0 \& \mathrm{t}=1331826363000$ [hereinafter KPCS].

15. Id.

16. See Wexler, supra note 5 , at 1728 (outlining international efforts to limit access to the disputed resources and only allow legitimate goods to reach the marketplace).

17. See generally PaUl Collier, The Bottom Billion: Why the Poorest Countries ARE Falling and What Can BE Done About It (2007) (arguing, inter alia, that the natural resources trap is one of four development traps that are preventing the poorest countries from producing the economic growth seen in much of the developing world).

18. See Shannon K. Murphy, Clouded Diamonds: Without Binding Arbitration and More Sophisticated Dispute Resolution Mechanisms, The Kimberley Process Will Ultimately Fail in Ending Conflicts Fueled by Blood Diamonds, 11 PEPP. DISP. RESOL. L.J. 207, 220-21 (2011).

19. See The Kimberley Process, GLOBAL wITNESS, http://www.globalwitness.org/cam paigns/conflict/conflict-diamonds/kimberley-process (last visited Nov. 16, 2011); Press 
The KP is open to all U.N. member states to join as Participants, while the diamond industry and civil society organizations act as official observers. ${ }^{20}$ Once admitted to the KP, Participants are mandated to "amend or enact appropriate laws or regulations to implement and enforce the Certification Scheme and to maintain dissuasive and proportional penalties for transgressions." ${ }^{21}$ Additionally, the KP requires governments "to certify the origin of rough diamonds, and put in place effective [internal] controls to prevent conflict stones from entering the supply chain."22 Participants can trade rough diamonds only with other member states, thus seeking to close the regulatory loop while incentivizing countries that wish to produce, trade, or process uncut diamonds to join. ${ }^{23}$ Further obligations on participants include utilizing tamper resistant containers, requiring each shipment of rough diamonds to be accompanied by a validated $\mathrm{KP}$ certificate, designating official import and export authorities, and collecting and maintaining relevant data on production, exports, and imports. ${ }^{24}$

The KP also establishes specific principles for transparency and cooperation that Participants agree to support in collecting and sharing information. ${ }^{25}$ The nonbinding statistical requirements are typical of the KP in stating, "Participants should . . . compile and make available to all other Participants through the Chair statistical data."26 States are also afforded broad discretion in determining national methodologies for data collection and in "[protecting] commercially sensitive information." 27 Nevertheless, through the KP information sharing mechanisms, states disseminate their relevant laws, regulations, and practices; their statistical data on rough diamond imports, exports, and number of certificates issued; and their self-assessments in order to establish best practices. ${ }^{28}$ Information and procedures are also to be shared through the KP peer review mechanism, in which

Release, Global Witness, Global Witness Leaves Kimberley Process, Calls for Diamond Trade to Be Held Accountable (Dec. 5, 2011), available at http://www.globalwitness.org/ sites/default/files/library/KPexity.pdf. See generally P'SHIP AFR. CAN., REAP WHAT YOU Sow: GREED AND CORRUPTION IN ZIMBABWE'S MARANGE DIAMOND FIELDS (2012), available at http://www.pacweb.org/images/PUBLICATIONS/Conflict_Diamonds_and_KP/Reap_Wh at_You_Sow-eng-Nov2012.pdf (discussing in depth the controversy surrounding Zimbabwe's Marange diamond fields).

20. Wexler, supra note 5, at 1743-44.

21. KPCS, supra note 14 , at 7.

22. The Kimberley Process, supra note 19.

23. $I d$.

24. KPCS, supra note 14, at 6-7.

25. See id. at 8.

26. Id

27. Id. at 16.

28. See Wexler, supra note $\mathbf{5}$, at $\mathbf{1 7 4 5}$. 
representatives from member states, the diamond industry, and NGOs visit individual states and report their findings. ${ }^{29}$

In addition to the requirements of Participants, the diamond industry's "voluntary self-regulation" is also included in the KP texts. ${ }^{30}$ The industry created a regulatory entity, the WDC, both to direct the industry's efforts to eliminate conflict diamonds from the market and to represent its interests within the KP. ${ }^{31}$ The System of Warranties established by the WDC attempts to fill the significant regulatory gap on the back end of the KP, which covers only rough, uncut diamonds. ${ }^{32}$ As such, the System of Warranties encourages companies to include a statement on invoices declaring the enclosed finished diamonds to be conflict-free. ${ }^{33} \mathrm{Also}$, the WDC prohibits members from knowingly buying or selling diamonds from noncompliant $\mathrm{KP}$ sources, and commits to punishing and publishing violators of the internal controls. ${ }^{34}$ For consumers who purchase a diamond that includes a System of Warranties statement, the polished stone will have received certification of its conflict-free status from the exporting and importing governments in addition to the industry itself. The system is widely adopted by diamond companies despite being voluntary, yet NGOs have shown verification and auditing mechanisms to be insufficient. ${ }^{35}$

From the outset, Global Witness and Partnership Africa Canada (PAC), two leading NGOs on resource extraction issues, have played a significant role as civil society's official observers to the KP. ${ }^{36}$ The emergence of conflict diamonds as a global issue can be traced largely to

29. Id. See also Kimberley Process, Administrative Decision: KPCS Peer Review System, Nov. 2006, available at http:/www.kimberleyprocess.com/documents/10540/11188 $12007 \% 20-\% 20 \mathrm{AD} 16 \% 20$ Peer\%20Review\%20revised.pdf [hereinafter KPCS Peer Review System] (outlining the provisions and processes governing the KP Peer Review system).

30. KPCS, supra note 14, at 2.

31. See About WDC: Mission Statement, WoRLD DIAMOND CounCIL, http://www.world diamondcouncil.org/index.php/about-wde/mission-statement (last visited Mar. 12, 2013) (describing the roles and objectives of the WDC).

32. See The Diamond Industry, supra note 12.

33. Id.

34. World Federation of DIAMOND Bourses, RESOlu'tions and RECOMMENDATIONS 24-25 (Sept. 2002), available at http://www.wfdb.com/PDFs/Statutes/Resolutions\&Recom mendations.pdf.

35. Press Release, Amnesty Int'l, Conflict Diamonds: Jewellers Keeping Consumers in the Dark (Oct. 18, 2004), available at http://www.amnesty.org/en/ibrary/info/POL30/038/ 2004/en (revealing study according to which leading diamond companies were failing to provide consumers with meaningful assurances that diamonds were conflict-free).

36. KP Basics, KimBerly Process, http://www.kimberleyprocess.com/web/kimberleyprocess/kp-basics (last visited Mar. 12, 2013). 
a Global Witness report published in $1998 .{ }^{37}$ Other civil society groups, along with governments and the diamond industry, responded to the report by acknowledging the problem and pledging to address it. ${ }^{38}$ Together, the two observer organizations, along with a number of other groups, provided the KP with needed on-the-ground expertise and monitoring capacity during its creation and development. ${ }^{39}$ Importantly, NGO criticism of the KP helped lead to the creation of the Monitoring Working Group, a permanent arm of the KP dedicated to assessing effective implementation by conducting review visits and annual reports of Participants. ${ }^{40}$ Ultimately, this strengthened the peer review mechanism and enforcement measures, which led to the voluntary withdrawal of Venezuela as an active participant in the KP. ${ }^{41}$ Despite using its position within the tripartite governing structure to push for reforms, civil society groups walked out of the June $2011 \mathrm{KP}$ plenary meeting in Kinshasa, DRC, citing the KP's failure to address human rights abuses. ${ }^{42}$ Currently, civil society, under the auspices of the Kimberley Process Civil Society Coalition, has a deteriorating relationship with the KP after boycotting the October-November 2011 plenary meeting and after Global Witness withdrew from its official observer status in December 2011. ${ }^{43}$

37. Global Witness, A Rough Trade: The Role of Companies and Governments IN THE ANGOLAN CONFLICT (1998), available at http://www.globalwitness.org/sites/default/ files/pdfs/A_Rough_Trade.pdf; Price, supra note 9, at 32.

38. See The Kimberley Process, supra note 19.

39. See generally Wexler, supra note 5 at 1752-55 (outlining the development of the KP's internal review system).

40. Monitoring, KIMBERLEY PROCESS, http://www.kimberleyprocess.com/web/kimberley -process/monitoring (last visited June 22, 2013).

41. Id. at 1752-53.

42. Press Release, Global Witness, Civil Society Expresses Vote of No Confidence in Conflict Diamond Scheme (June 23, 2011), available at http://www.globalwitness.org/lib rary/civil-society-expresses-vote-no-confidence-conflict-diamond-scheme.

43. Press Release, Global Witness, Kimberley Process Lets Zimbabwe Off the Hook (Again) (Nov. 2, 2011), available at http://www.globalwitness.org/library/kimberleyprocess-lets-zimbabwe-hook-again. In response to civil society's boycott, the Plenary's Final Communiqué stated, "The Plenary reaffirmed its commitment to continue its constructive engagement with Civil Society in recognition of the role that Civil Society plays in the KP." Kimberley Process, Final COMmINiqué from the KimberLey Process Plenary MEETING 7 (2011), available at http://kp.gjepc.org/pdf $/ 1218$ Plenary_20 11_Final_Communique_en.pdf. 


\section{The KImberley Process Has ImProved THE Rough Diamond TRADE, BUT ITS OVERLY STATIST APPROACH PREVENTS THE FULL LEVERAGING OF ITS TRIPARTITE GOVERNING STRUCTURE}

In assessing the performance of the KP during its first decade, the successes and the failures are both attributable to the KP's founding precepts. First, the definition of conflict diamonds, around which much of the institutional architecture was built, is strikingly limited and statist. Secondly, voting rights are restricted to participating states and all decisions must be made by consensus. ${ }^{44}$ Thirdly, the legal framework is thin, comprised mostly of recommendations for state practice instead of imposing obligations. ${ }^{45}$ Finally, the promising tripartite governing structure is failing to be fully leveraged because civil society's pivotal monitoring and enforcement role is undermined by the KP's uncompromising desire to protect a robust consumer market and by inadequate access to information. This final component will be discussed in Part IV.

\section{A. The KP Applies a Limited Definition of Conflict Diamonds}

The definition of conflict diamond is of paramount importance to the KP because it establishes the scope of the KP's target. In adopting a narrow approach to the problem, the KP defines conflict diamonds as "rough diamonds used by rebel movements . . . to finance conflict aimed at undermining legitimate governments." 46 This statist definition is derived from U.N. General Assembly Resolution 55/56. ${ }^{47}$ By categorizing success as preventing rebel groups from trading illicit diamonds, the KP strengthens diamond-exporting governments. Throughout the 1990s, rebel groups were using illicit diamonds to fund violence against recognized governments, with Angola as a primary example. ${ }^{48}$ Regardless, the definition's minimizing scope sees the role of diamonds in fueling conflicts as excessively black-and-white. ${ }^{49}$ Conflict diamonds are not simply the product of a system in which illegitimate rebels

44. KPCS, supra note 14 , at 4,9 .

45. See Wexler, supra note 5, at 1747-48, 1751.

46. KPCS, supra note 14 , at 3 .

47. G.A. Res. 55/56, supra note 2 , at 1 .

48. See generally GLOBAL WITNESS, supra note 37 (discussing Angola).

49. See Alexandra R. Harrington, Faceting the Future: The Need For and Proposal of the Adoption of a Kimberley Process-Styled Legitimacy Certification System for the Global Gemstone Market, 18 TRANSNAT'L L. \& CONTEMP. PROBS. 353, 362 (2009) (arguing that "the Kimberley Process still has a weak scope of application given the extent to which states can use diamonds to fund illegal conduct"). 
operate against "legitimate governments." 50 As a result of this false premise, the KP makes no exceptions for groups whose principal purpose is to confront a repressive regime or to combat human rights abuses. ${ }^{51}$

Such a statist definition may have been necessary to achieve the stated goal of enabling the "widest possible participation in the Certification Scheme." 52 Additionally, the definition is not a product of governments and the industry alone, as civil society was engaged in the negotiations on these foundational issues. ${ }^{53}$ While such valid arguments can be made for the necessity of this definition of conflict minerals and for the wide acceptance it garnered, the effects of selecting the funding of rebel groups as the institution's target still present the KP with legitimacy issues. ${ }^{54}$ If the role of governments is excluded from the conflict diamond problem, then it becomes imperative to involve civil society in the process. Otherwise, KP is protecting governments and the industry is seeing a more secure product, while the conditions endured by those in the diamond extracting areas are an afterthought.

Progress toward broadening the definition of conflict diamond was made throughout 2012 as the United States used its term as chair of the $\mathrm{KP}$ to promote the idea. ${ }^{55}$ Unfortunately, no consensus was reached on amending the definition at the 2012 plenary meeting, but the final communiqué encouraged further "discussions and consultations on the subject of conflict diamond definition." 56 Civil society groups have sought an expanded definition for years, ${ }^{57}$ but it remains to be seen if

50. See Shannon Raj, Note, Blood Electronics: Congo's Conflict Minerals and the Legislation that Could Cleanse the Trade, 84 S. CAL. L. REV. 981, 985-87 (2011) (explaining, with regard to the role of resources in the context of conflict in the Democratic Republic of the Congo, that "one of the common threads among these struggles is that the various groups involved seek to obtain and sustain power through their control of the mineral mines").

51. Wexler, supra note 5, at 1730-31.

52. Interlaken Declaration; supra note 1 , at 1.

53. Wexler, supra note 5, at 1729-30.

54. See id. at 1730-31 (noting that "the institution does not directly address all diamond-related abuses; instead, it engages states and corporations by creating a coalition to address third party abuses").

55. See Milovanovic, A Note from Ambassador Milovanovic, KIMBERLEY Process (Feb. 20, 2012, 4:17 PM), http://www.kimberleyprocess.com/web/kimberley-process/blog/-/blogs/a -note-from-ambassador-milovanovic ("[W]e see diamonds emerging from conflicts that do not involve the same types of rebel movements, but from broader contexts of conflict, and we believe the KP should carefully consider how best to address this.").

56. Kimberley Process, Final Comminiqué from the Kimberley Process Plenary MEETING 7 (2012), available at http://www.kimberleyprocess.com/documents/10540/49668/ 2012\%20Washington\%20Plenary\%20Communique.pdf.

57. See, e.g., Conflict Diamonds Today, PAC, http://www.pacweb.org/en/conflict-dia monds-today (last visited Mar. 12, 2013) (stating that "PAC has long called for a newer 
the renewed emphasis put on the issue by the United States can overcome the consensus requirement.

Despite the limitations on the KP imposed by its definition of conflict diamonds, the KP has been successful at reducing the role of diamond extraction as a source of funding for conflicts. ${ }^{58}$ According to the World Diamond Council, less than 1 percent of rough diamonds meet the definition of conflict diamonds. ${ }^{59}$ While publishing different statistics than those presented by the WDC, both Global Witness and PAC recognize that progress has been made under the KP. ${ }^{60}$ However, despite agreement on the fundamental improvements seen as a result of the coordinated effort to prevent conflict diamonds from entering the market, the differences in quantifying the extent of the progress provided by the WDC and PAC are distressing. While the WDC claims that 99 percent of the world's diamonds are conflict-free, PAC suggests that it remains difficult to quantify what share of annual global production conflict diamonds represent. ${ }^{61}$ The successes produced by the $\mathrm{KP}$ are significant, ${ }^{62}$ including a reduction in conflict diamonds and an

and broader definition of conflict diamonds that reflects the role state actors play in human rights abuses in diamond zones"). See also Julie Elizabeth Nichols, A Conflict of Diamonds: The Kimberley Process and Zimbabwe's Marange Diamond Fields, 40 DENV. J. INT'L L. \& POL'Y. 648, 675 (suggesting that substitution of the word "illicit" for "conflict" in the definition would remove the KP's approval of exports from the Marange fields in Zimbabwe).

58. See The Kimberley Process Certification Scheme, Third Year Review 15 (2006), available at http://www.worlddiamondcouncil.org/download/resources/documents/ Kimbeley\%20Process\%20Third\%20Year\%20Review\%20\%281-11-2006\%29.pdf.

59. World Diamond Council, Conflict Diamonds and the Kimberley Process FACT SHEET (2008), available at http://www.worlddiamondcouncil.org/download/resources/ documents/Fact\%20Sheet\%20(Conflict\%20Diamonds\%20and\%20the\%20Kimberley\%20Pro cess).pdf.

60. See The Kimberley Process, supra note 19 (stating that "the Kimberley Process has chalked up some notable achievements in the past ten years"); P'SHIP AFR. CAN., DIAMONDS AND HUMAN SECURITY: ANNUAL REVIEW 2009, at 2 (2009), available at http://www.pacweb.org/Documents/annual-reviews-diamonds/AR_diamonds_2009_eng.pdf (claiming that, despite continuing problems, some progress has been made through the KPCS).

61. Conflict Diamonds Today, supra note 57.

62. Notable successes produced by legitimate diamond revenues can be seen in Botswana over the course of several decades and in Sierra Leone over the past few years. Botswana has transformed itself into a middle-income country since it became independent in 1966, largely through the extraction and export of diamonds. On the other hand, partially as a result of robust diamond exports, Sierra Leone recently completed an IMF program that helped it stabilize economic growth and lower inflation. However, despite these positive effects, over-reliance on diamonds is a significant economic issue that threatens both countries' ability to sustain their recent improvements. See The World Factbook: Botswana, CIA (Mar. 26, 2013), https://www.cia.gov/library/publications/the- 
increase in official diamond revenues, but the wide disparity regarding the degree of those achievements speaks to a pressing problem of information to be addressed further in Part IV. ${ }^{63}$

\section{B. The KP Decision-Making Mechanisms are Insufficient when Decisive Action Needs to be Taken}

In addition to applying a statist definition of conflict diamonds, the KP restricts voting rights to participants' governments. ${ }^{64}$ Further, all decisions, from addressing proposals for reform to taking enforcement actions against participants, must pass a consensus voting system. ${ }^{65}$ Should consensus be impossible, which is quite conceivable given the fifty participants, the KP calls for the chair to "conduct consultations."66 The decision to mandate consensus voting was made to incentivize breadth of participation by "acknowledging that state sovereignty should be fully respected."67 Yet, consensus decision-making has led to weak enforcement measures and has undermined the KP's deterrence effect. 68 When called on to address the most pressing issues affecting the certification regime's legitimacy, such as human rights abuses at the Marange mines in Zimbabwe, the mining of diamonds in prohibited areas in Cote d'Ivoire, and the continued intransigence of Venezuela, the KP has produced insufficient solutions. ${ }^{69}$ With the tripartite governing regime fractured by the boycott of civil society at the most recent annual meeting and Global Witness's withdrawal, the consensus

world-factbook/geos/bc.html; The World Factbook: Sierra Leone, CIA (Mar. 26, 2013), https://www.cia.gov/library/publications/the-world-factbook/geos/sl.html.

63. See The Kimberley Process, supra note 19.

64. Wexler, supra note 5 , at 1750.

65. Id. at 1751 .

66. KPCS, supra note 14, at 9. Among the fifty Participants, the European Community and its member governments count as one Participant. See id. at 4.

67. $I d$. at 2.

68. See, e.g., De BeERS FAMILY of Cos., RePort to Society 2009, at 37 (2010),

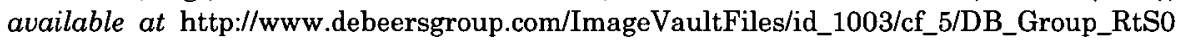
9.PDF; The Kimberley Process, supra note 19.

69. See Press Release, Global Witness, supra note 19; Wexler, supra note 5, at 1769-75. At the 2011 Kinshasa Plenary meeting, the Plenary approved exports from Zimbabwe's Marange diamond fields over the objections of civil society. Kimberley Process, Administrative Decision on Marange [Zimbabwe] (Nov. 1, 2011), available at http://www. kimberleyprocess.com/documents/10540/40001/2011\%20-\%20AD31\%20Marange\%20(Zim babwe).pdf;jsessionid=6931 A9E07A0C45271682589C3AD02597?version=1.1\&t=13275951 70000. The decision allowing Zimbabwe to export diamonds from Marange came two years after Participants took up the issue of expulsion at the 2009 Plenary, at which time consensus was blocked by countries such as Russia, South Africa, Namibia, Tanzania, and the DRC. Wexler, supra note 5, at 1772. 
requirement is an impediment to making the reforms necessary to strengthening the KP's legitimacy by empowering governments at the expense of other critical parties. ${ }^{70}$

\section{The KP Operates Within a Thin Legal Framework that is Dependent on Domestic Law}

As another inducement to broaden participation in the KP, the designers created a thin legal regime. ${ }^{71}$ The core documents stress respect for state sovereignty and impose few specific obligations on Participants, while intentionally avoiding treaty-like language. ${ }^{72}$ However, each government must enact domestic legislation to enforce the KP in order to be admitted. ${ }^{73}$ Thus, while each state retains great discretion in developing its own legislation and internal controls, all fifty-four participating jurisdictions now have a body of domestic law implementing KP provisions. ${ }^{74}$ In designing the $\mathrm{KP}$ with minimal international legal requirements, the founding parties lowered the costs for states to join by reducing the potential for constraints on behavior. ${ }^{75}$ This has triggered one of the KP's great successes, extending membership to countries encompassing 99.8 percent of the global production of rough diamonds. ${ }^{76}$ Nevertheless, with nearly all the world's rough diamonds covered by the KP, its inability to effectively monitor or enforce its provisions is a direct effect of the weak legal regime in place. Assuming few states will accept a loss of sovereignty by adopting a more expansive legal framework, it is imperative that civil society be allowed to augment the KP's monitoring and enforcement mechanisms within the existing legal structure.

70. In contrast, the World Trade Organization (WTO) uses a "reverse consensus" model in its dispute settlement process. Thus, when a dispute resolution panel finds a violation of WTO rules and authorizes sanctions, the ruling will be enforced unless there is consensus opposing the decision. This model, which takes an approach opposite to that of the $\mathrm{KP}$, has produced a formidable enforcement regime. See WTO Bodies Involved in the Dispute Settlement Process, Dispute Settlement System Training Module, WoRLD TRADE ORG., http://www.wto.org/english/tratop_e/dispu_e/disp_settlement_cbt_e/c3s1p1_e.htm (last visited Mar. 12, 2013).

71. See Wexler, supra note 5 , at $1747-48$.

72. Id. at 1748 .

73. KPCS, supra note 14 , at 7 .

74. See Wexler, supra note 5, at 1748; Participants, KIMBERLEY Process, http://www. kimberleyprocess.com/web/kimberley-process/kp-participants (noting that, of the fifty-four Participants, the European Union and its member states count as one Participant) (last visited June 22, 2013).

75. See id. at $1746-47$.

76. KP Basics, supra note 36 . 
Interested parties have put forward numerous proposals for reform, with enhanced roles for civil society groups a common theme. ${ }^{77}$ Arguments for where civil society's particular expertise can be leveraged to improve the KP's functioning include, but are not limited to, training customs officials, monitoring compliance, observing fair and objective decision-making processes, and scrutinizing the industry's performance under the System of Warranties and related initiatives. ${ }^{78}$ Implementation of proposals put forward during the chairmanship of the United States in 2012-calling to broaden the KP's definition of "conflict diamonds" and to create a permanent secretariat79-would further the need for civil society monitoring as diamond-funded violence by participating governments would fall under the KP's remit and the independence of KP staff would need to be maintained. Nevertheless, the legal documents underpinning the KP limit the extent of the changes currently possible and the reliance on domestic law complicates implementation of centralized reforms.

\section{The KP Must Permit CIVIl SOCIETy to Play a Greater Role IN MONITORING COMPLIANCE AND IN INSTITUTING ENFORCEMENT ACTIONS AGAINST VIOLATORS FOR THE KP TO MAINTAIN ITS LEGITIMACY}

Following the departure of one of civil society's two official observers and the boycott of the Kinshasa plenary meeting, the KP is at risk of operating largely with only governments and the industry as the participating parties. ${ }^{80}$ This structure diminishes the legitimacy of the $\mathrm{KP}$ by removing the component without a financial stake in the production of rough diamonds. In order to remain a viable international mechanism, the KP must strengthen the role of civil society to balance the power placed in member governments and the diamond industry. As it now stands, the KP is subject to charges of being more amenable to the interests of Zimbabwe's government, led by Robert Mugabe, than it is to the concerns of founding partners Global Witness and PAC. ${ }^{81}$ Both

77. See, e.g., IAN SMILLIE, PADDLES FOR KIMBERLEY: AN AGENDA FOR REFORM (2010), available at http://www.pacweb.org/images/PUBLICATIONS/Conflict_Diamonds_and_KP /Paddles_for_Kimberley-June_2010.pdf; Milovanovic, supra note 55.

78. See SMILLIE, supra note 77, at 2.

79. See Milovanovic, supra note 55.

80. See NGOs Walk Out of Kinshasa KP Meeting, Consider Options, OTHER FACETS (P'ship Afr. Can., Ottowa, Ont.), Aug. 2011, at 1, available at http://www.pacweb.org/Docu ments/Other-Facets/OF35-eng.pdf.

81. See Charmian Gooch, Why We Are Leaving the Kimberley Process-A Message From Global Witness Founding Director Charmian Gooch, GLOBAL WITNESS (Dec. 5, 2011), http://www.globalwitness.org/library/why-we-are-leaving-kimberley-process-messageglobal-witness-founding-director-charmian-gooch (stating as a reason for Global Witness's 
the optics of this situation within the international community and the implications for those in diamond mining communities are weakening a critically needed system for eliminating diamonds as a funding source for conflict.

Given the current state of the KP, three areas necessitate giving more robust powers to the remaining civil society groups, while also seeking to reengage Global Witness. First, the decision to authorize diamond exports from Zimbabwe's Marange region has distanced civil society from established internal enforcement mechanisms. Second, despite their concerns going unheeded by KP Participants, NGOs retain significant power to oppose the entry of conflict diamonds into the market through their ability to influence consumer perceptions. Finally, greater information sharing is necessary, particularly where the industry is currently subject only to self-regulation, so that the tripartite structure can be fully leveraged.

\section{A. Authorizing Exports from the Marange Region Alienated Civil Society Within the KP}

One of the foremost achievements of the KP is bringing mineral revenues that previously operated outside of state coffers into the formal economy. ${ }^{82}$ Further, diamond companies, principally De Beers, have become more transparent and pledged to stop purchasing from groups in conflict zones. ${ }^{83}$ From the beginning, it was acknowledged that the legitimacy of the KP could not rest solely on the industry and government participation. ${ }^{84}$ Rather, due to the pivotal role played by NGOs in initially recognizing the problem and in their ability to affect consumer behavior, civil society had to be given a seat at the table. Despite intimate involvement in the KP, from its development to the present, civil society's ability to influence the KP's actions has reached a nadir. ${ }^{85}$ If the KP is to avoid further allegations of acting solely in the interest of increasing revenues, the governments and the industry with

departure from the Scheme, "the decision to endorse unlimited diamond exports from named companies in the Marange region of Zimbabwe-the scene of mass killings by the national army-has turned an international conflict prevention mechanism into a cynical corporate accreditation scheme").

82. See The Kimberley Process, supra note 19.

83. See Wexler, supra note 5, at 1719, 1734-36, 1741, 1744.

84. Cf. id. at 1736 (arguing that skeptics would never find that a coalition of states and industry alone would establish an adequate mechanism for addressing the human rights concerns associated with conflict diamonds).

85. See Press Release, Global Witness, supra note 42 (arguing that the KPCS is failing to meet its core commitments while "[r]espect and support for civil society, as an integral member of the tripartite structure of the KP, is being eroded"). 
a financial stake in the diamond trade must reemphasize civil society's position within the organization.

When awareness of the abuses occurring in the Marange fields at the hands of the Zimbabwean armed forces became widespread in 2009-human rights groups had documented violence and abuse since 2006-the KP took action to prevent exports. ${ }^{86}$ Following a review mission that concluded Zimbabwe was noncompliant with KP requirements, the $2009 \mathrm{KP}$ Plenary Meeting established an action plan with Zimbabwe in which the country agreed to an export ban until monitors were in place and progress was made. ${ }^{87}$ By adopting this course of action, the KP pursued a middle ground weaker than the suspension advocated by civil society groups and by the review mission's report. ${ }^{88}$ Further, despite the substantial efforts of civil society to chronicle the abusive activities of the Zimbabwean government at the Marange fields, the door was left open for Zimbabwe to quickly return to the diamond market.

Civil society boycotted the $2011 \mathrm{KP}$ plenary meeting in Kinshasa because their concerns were realized with the decision to allow exports from Zimbabwe's Marange diamond fields. ${ }^{89}$ The decision included provisions requiring a KP Monitoring Team to verify compliance and mandating "KP Civil Society Coalition representatives in Zimbabwe will have access to the Marange area."90 Despite these caveats, the decision to allow the exportation of diamonds extracted from the Marange region opens significant revenue streams for the Zimbabwean government in Harare and diamond companies. ${ }^{91}$ This "business deal" 92 was made in contravention of evidence supplied by civil society linking diamonds in Marange to continued human rights abuses and violence. ${ }^{93}$ Because of

86. See Nichols, supra note 57 , at $668-69$.

87. Id. at 669 .

88. Zimbabwe, GLOBAL WITNESS, http://www.globalwitness.org/campaigns/conflict/confl ict-diamonds/zimbabwe (last visited Mar. 12, 2013).

89. See Press Release, Global Witness, supra note 42.

90. Kimberley Process, supra note 69, at 1.

91. See Zimbabwe, supra note 88 (noting suggestions that the Marange fields "could be home to one of the world's richest diamond deposits").

92. Press Release, Global Witness, supra note 42 (quoting noted Zimbabwean human rights activist Farai Maguwu).

93. See generally Global Witness, Return of the Blood Diamond: THe Deadly RACE TO CONTROL ZimBABWE'S NEW-FOUND DiAMOND WEALTH 2, 6-8 (2010), available at http://www.globalwitness.org/sites/default/files/pdfs/return_of_blood_diamond.pdf (stating that the Marange diamond fields have been the site of violent assaults, killings, beatings, rapes, and forced labor at the hands of the government security forces); HUMAN RIGHTS Watch, Diamonds in the Rough: Human Rights abuses in the Marange Diamond FIELDS OF ZIMBABWE (2009) (stating, at page 3, that Zimbabwe's armed forces "are engaging in forced labor of children and adults and are torturing and beating local 
the persistent human rights violations committed by the Zimbabwean armed forces, civil society groups alleged that Zimbabwe did not meet $\mathrm{KP}$ minimum requirements and was in breach of the 2009 agreement to undertake reforms ${ }^{94}$ Accordingly, NGOs strongly urged the KP not to authorize the shipment of diamonds from the Marange fields. ${ }^{95}$

In going directly against the calls of the NGO community, the Marange decision both jeopardized the legitimacy of the tripartite structure and too strictly adhered to the limited KP definition of conflict diamond. ${ }^{96}$ In addition to presenting substantial evidence of violations and publicly denouncing the violent actions around Marange, civil society groups voiced their concerns at official KP fora. ${ }^{97}$ As such, NGOs were attempting to wield power within the established KP framework, while also fulfilling the monitoring function such groups perform for their broader constituencies. Yet, organizations involved in the KP since its founding are increasingly being pushed outside its mechanisms. ${ }^{98}$ Thus, the loss of Global Witness is a paradigm-shifting blow to the KP.99 By acting in the face of mounting proof of diamond-fueled abuses, governments and the industry have put the KP's survival at risk.

\section{B. Civil Society May be Forced to Pursue External Enforcement Mechanisms}

The KP's credibility remains on tenuous ground in 2013 following the pull out of a vital founding organization and widespread condemnation of its decision to allow exports from the Marange fields. 100

villagers"); Hilary Andersson, Marange Diamond Field: Zimbabwe Torture Camp Discovered, BBC NEwS (Aug. 8, 2011, 1:40 AM), http://www.bbc.co.uk/news/world-africa14377215.

94. See Global WITNESS, supra note 93 , at 4 .

95. See id.

96. See Nichols, supra note 57, at 664 (stating that "diamonds from Marange do not fit comfortably within the KP's codified scope; no rebel group uses these diamonds to fund war").

97. See Kimberley Process, Kimberley Process Plenary Session: Communiqué 3 (2009), available at http://www.state.gov/documents/organization/133852.pdf.

98. See Press Release, Global Witness, supra note 42 (quoting the president of the Liberian organization Green Advocates as saying, "KP member governments and the diamond industry seem ready to turn their back on the interests of Zimbabwe's citizens, the public good and the principles on which the Kimberley Process was founded").

99. See generally Theo Leggett, Global Witness Leaves Kimberley Process Diamond Scheme, BBC NEWS (Dec. 4, 2011, 11:38 PM), available at http://www.bbc.co.uk/news/busi ness-16027011 (detailing the problems plaguing the KP leading up to the departure of Global Witness).

100. See Celia W. Dugger, Zimbabwe Diamond Exports Approved over Objections, N.Y. TIMES, June 24, 2011, http://www.nytimes.com/2011/06/25/world/africa/25zimbabwe.html? 
Further, participating governments and the diamond industry are failing to recognize that a vibrant diamond market is dependent on the reputation of the product itself. 101 Global Witness and PAC became official observers to the KP, rather than advocates of a complete ban on the diamond trade, because diamonds can be a source of revenue for deeply impoverished regions and countries, thus aiding governments that support human rights, while also reducing conflicts. ${ }^{102}$ Yet, should the $\mathrm{KP}$ fail to enforce its provisions in the face of acknowledged violence, civil society may be forced to exert its enforcement capacity outside the KP.

The diamond industry, while strikingly transnational in its supply chain and financial flows, is uniquely susceptible to alterations in consumer opinion. ${ }^{103}$ The value of the product sold by diamond corporations is founded largely not on its utility, but on an intrinsic value derived from consumers' perceptions of what a diamond represents. ${ }^{104}$ As such, if the image associated with diamonds is human suffering rather than timeless elegance, the value of the product will significantly decline. Fears of the effects from such a public campaign against diamonds are largely responsible for the diamond industry's initial participation in the KP. ${ }^{105}$ While it is difficult to disassociate diamonds from the marital engagement and the wealth they have come to symbolize throughout much of the world, the fur industry's significant decline as a result of public distaste for the methods of production is instructive. 106

Given this market fragility, civil society possesses the power to affect consumer behavior through messaging that overshadows diamond marketing, such as De Beers' "A Diamond Is Forever" campaign. ${ }^{107}$ Yet, in pursuing a campaign to advocate a consumer boycott due to the continued role of diamonds in funding conflict, civil society would be

_r=1\&scp=2\&sq=Marange\&st=cse (noting objections from the United States, Canada, and the European Union to the authorization of exports of diamonds mined in the Marange fields).

101. See Anne E. Andrews, Note, A Diamond Is Forever: De Beers, the Kimberley Process, and the Efficacy of Public and Corporate Co-Regulatory Initiatives in Securing Regulatory Compliance, 2 S.C. J. INT'L L. \& BUS. 177, 202-03 (2006).

102. See Wexler, supra note 5, at 1737-38.

103. See Ann C. Wallis, Note, Data Mining: Lessons from the Kimberley Process for the United Nations' Development of Human Rights Norms for Transnational Corporations, 4 NW. U. J. INT'L HUM. RTS. 388, 399-400 (2005).

104. Id. at 399.

105. Price, supra note 9, at 32.

106. Id. at 33; see also Karen E. Woody, Diamonds on the Souls of Her Shoes: The Kimberley Process and the Morality Exception to WTO Restrictions, 22 CONN. J. INT'L L. 335,343 (2007).

107. See Andrews, supra note 101, at 196-97, $202-03$. 
harming the diamond industry as well as its own interests in a legitimate diamond trade. 108

The KP is in a precarious position following the boycott of civil society at the Kinshasa plenary meeting. NGOs involved with diamond trade issues are responsible to their constituents across the globe for creating a better human rights environment. ${ }^{109}$ Given that, these organizations cannot sit by idly while the KP allows diamonds to be exported from regions where governments have engaged in violence or enriched individual ministers through smuggling. ${ }^{110}$ However, civil society shares an interest in the success of the KP, with full implementation and further improvements in the certification process only possible with its participation. ${ }^{111}$ Taking into account the power held by civil society to change consumer perceptions of diamonds through its social capital, it is in the interests of participating governments and the diamond industry to fully reengage civil society in the wake of Global Witness's departure. That is an outcome NGOs should welcome, but accompanying that result must be greater influence within the KP so that decisions never again can be characterized as a "business deal."

\section{Civil Society Needs Greater Access to Information if the KP is to Improve its Effectiveness}

Should the KP renew its commitment to working with civil society as a genuine partner in the KP, greater information sharing must follow so that NGOs can more effectively exercise their monitoring capacity. As a commodity tracking system, the KP is dependent on accurate and comprehensive information being provided by the actors most intimately involved in the production and movement of rough diamonds.112 Yet, while the KP does suffer from inadequate

108. Wallis, supra note 103 , at 399 .

109. See, e.g., About Global Witness, GLOBAL WITNESS, http://www.globalwitness.org/abo ut-us (last visited Mar. 12, 2011).

110. See Press Release, Global Witness, supra note 42.

111. See Wallis, supra note 103, at 399; PAC and the Kimberley Process: A History, PAC, http://www.pacweb.org/en/pac-and-the-kimberly-process (last visited Jan. 03, 2013) (stating that "the KP is too important to fail, and the prospect of a return to a world in which such a potentially dangerous commodity is unregulated is not an option").

112. Cf. Christiana Ochoa \& Patrick J. Keenan, Regulating Information Flows, Regulating Conflict: An Analysis of United States Conflict Minerals Legislation, 3 GOETTINGEN J. INT'L L. 129, 139 (2011) (summarizing the central idea of information forcing schemes as "to move information from the entity best situated to hold or obtain information (the corporation) to the entity most likely to use it for the protection of public interests (civil society and regulators)"). 
information, ${ }^{113}$ its problems primarily concern a lack of accountability after information has been disseminated.114 Given the state-centric nature of the certification scheme, it remains possible for conflict diamonds to be mixed with the legitimate supply chain through smuggling and processes such as transshipment.115 As such, further auditing mechanisms will increase the efficacy of the KP by augmenting the industry and government monitoring efforts already in place, while simultaneously integrating civil society observers. ${ }^{116}$

As the KP risks illegitimacy with a collapsing tripartite structure in the wake of failures epitomized by the inability to stand up to Zimbabwe, heightened information sharing and transparency become even more needed. The diamond trade involves numerous states at various production stages, including being mined across four continents, sorted in London, dealt in Antwerp, processed in one of thirty countries, cut in southern Africa or South Asia, and manufactured in Israel.117 The $\mathrm{KP}$ deserves praise for reducing the presence of conflict diamonds in the supply chain, but the complexity of the trade's global architecture requires greater access to industry information. ${ }^{118}$ The diamond industry's System of Warranties is an important part of establishing mine-to-retailer checks, but auditable information on polished diamonds must be made available to the industry's partners in the tripartite structure. ${ }^{119}$ Unlike respecting civil society's mandated position in $\mathrm{KP}$ decision-making procedures, which would not require alterations in existing law, participating governments should use domestic legislation to pressure the industry into producing information on diamond

113. See Carolyn T. Francis, U.S. DePt. of Commerce, Kmmberley Process Working

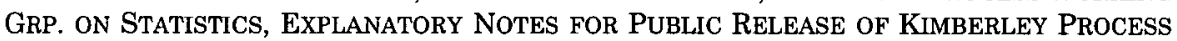
CERTIFICATION SCHEME DATA (2011), available at https://kimberleyprocessstatistics.org/ static/pdfs/NotesForKPCSPublicRelease.pdf (stating that "users of [KPCS] data should be aware that since each Participant reports their [sic] own statistics and that reporting practices might vary between Participants, the KPCS does not guarantee the quality, accuracy or consistency of the data presented").

114. See The Diamond Industry, supra note 12.

115. See Woody, supra note 106, at 346 (describing the problem of transshipment, where diamonds pass through a country in transit prior to arrival at the final destination, with potential for fraudulent origination claims to arise in countries that loosely monitor goods that are temporarily passing through their borders).

116. See SMILLIE, supra note 77 , at 11-12 (making recommendations for improved auditing systems).

117. See Price, supra note 9, at 29-30. This list of locations throughout the supply chain is not comprehensive.

118. See The Diamond Industry, supra note 12.

119. See Press Release, Amnesty Int'l, supra note 35. 
origination beyond the statement of conflict-free status issued by companies. ${ }^{120}$

Ultimately, producing a greater volume of information on diamonds later in the supply chain strengthens the validity of $\mathrm{KP}$ certification by closing a loophole for conflict diamonds to enter the market. Additionally, governments, with their import and export data, and NGOs, with their on-the-ground monitoring capacity, would be able to participate in a part of the KP now left exclusively to industry self-regulation. Pivotally, moving forward, such information on polished and finished stones would allow civil society to monitor what companies are purchasing conflict diamonds from regions such as Marange, should internal enforcement mechanisms continue to falter. ${ }^{121} \mathrm{By}$ forcing corporations to provide greater information than merely what is suggested by the System of Warranties, the KP would move closer to utilizing the potential for which its tripartite structure was initially lauded.

\section{CONCLUSION}

The KP addresses an issue so critical to diamond-producing countries and to global consumers that it must not fail. Yet, participating governments and the industry are taking the KP in a direction that contravenes the efforts of its civil society observers. By authorizing the export of diamonds from Zimbabwe's Marange fields over civil society's boycott in 2011, the KP lost Global Witness's wealth of expertise and placed its fledgling legitimacy in grave jeopardy. The KP's overly statist design created structural weaknesses that have allowed today's problems to emerge. Still, by reintegrating civil society into the certification scheme and by forcing greater information sharing, the KP can survive to continue reducing diamonds' role in financing conflict and other abuses. For the future prospects of a robust diamond market and of diamond extraction as a development tool, the three pillars of the tripartite structure must work together to reinvigorate civil society's status in the KP. Otherwise, the withdrawal of Global Witness may signal the beginning of the end for a once collaborative and innovative institution.

120. See, e.g., Ochoa \& Keenan, supra note 112, at 131 (describing disclosure requirements imposed on companies covered by the Dodd-Frank Wall Street Reform and Consumer Protection Act as an example of information-forcing legislation).

121. In contrast to the way the KPCS defines conflict diamonds, Global Witness defines them as "diamonds that are used to fuel violent conflict and human rights abuses." Conflict Diamonds, GLOBAL WITNESS, http://www.globalwitness.org/conflict-diamonds (last visited April 1, 2013). 